\title{
The Contribution of Endothelial-Mesenchymal Transition to Atherosclerosis
}

\author{
Jinyu Zhang ${ }^{1,2}$, Stella C. Ogbu ${ }^{1}$, Phillip R. Musich ${ }^{1}$, Douglas P. Thewke ${ }^{1}$, Zhiqiang Yao ${ }^{2}$ and Yong Jiang ${ }^{1, *}$ \\ 1 Department of Biomedical Sciences, J. H. Quillen College of Medicine, East Tennessee State University, \\ Johnson City, TN 37614, USA; zhangj2@etsu.edu (J.Z.); ogbusc@etsu.edu (S.C.O.); musichp@etsu.edu (P.R.M.); \\ thewke@etsu.edu (D.P.T.) \\ 2 Division of Infectious, Inflammatory and Immunologic Diseases, Department of Internal Medicine, \\ Quillen College of Medicine, East Tennessee State University, Johnson City, TN 37614, USA; yao@etsu.edu \\ * Correspondence: jiangy2@etsu.edu; Tel.: +1-423-439-4918
}

Citation: Zhang, J.; Ogbu, S.C.; Musich, P.R.; Thewke, D.P.; Yao, Z.; Jiang, Y. The Contribution of Endothelial-Mesenchymal Transition to Atherosclerosis. Int. J. Transl. Med. 2021, 1, 39-54. https://doi.org/ $10.3390 /$ ijtm1010004

Academic Editor: Pier Paolo Claudio

Received: 31 March 2021

Accepted: 24 May 2021

Published: 31 May 2021

Publisher's Note: MDPI stays neutral with regard to jurisdictional claims in published maps and institutional affiliations.

Copyright: (c) 2021 by the authors. Licensee MDPI, Basel, Switzerland. This article is an open access article distributed under the terms and conditions of the Creative Commons Attribution (CC BY) license (https:/ / creativecommons.org/licenses/by/ $4.0 /)$
Abstract: Atherosclerosis is a chronic progressive condition in which the wall of the artery develops abnormalities and causes thickening of the blood vessels. The development of atherosclerosis is a complex process characterized by vascular inflammation and the growth of atherosclerotic plaques that eventually lead to compromised blood flow. The endothelial to mesenchymal transition (EndMT) is a phenomenon whereby endothelial cells lose their endothelial properties and acquire a mesenchymal phenotype similar to myofibroblast and smooth muscle cells. This process is considered a key contributor to the development and, importantly, the progression of atherosclerosis. Thus, therapeutically targeting the EndMT will provide a broad strategy to attenuate the development of atherosclerosis. Here, we review our current knowledge of EndMT in atherosclerosis including several key pathways such as hypoxia, TGF- $\beta$ signaling, inflammation, and environmental factors during the development of atherosclerosis. In addition, we discuss several transgenic mouse models for studying atherosclerosis. Taken together, rapidly accelerating knowledge and continued studies promise further progress in preventing this common chronic disease.

Keywords: atherosclerosis; EndMT; inflammatory; TGF- $\beta$; hypoxia

\section{Introduction}

Atherosclerosis is a major vascular disease that causes death and morbidity worldwide [1]. In the United States, it is considered the major cause of cardiovascular diseases. About $0.2 \%$ of the population dies of heart disease every year. That means that $25 \%$ of cardiovascular disease deaths are derived from atherosclerosis. Coronary heart disease is the leading cause of death in the Western world, killing over $0.1 \%$ of people annually. On average, about $0.2 \%$ of Americans have a heart attack every year. Out of these, $71 \%$ have an initial attack, and $29 \%$ have a recurrent attack. Around $75 \%$ of acute myocardial infarctions occur from plaque rupture; the highest incidence of plaque rupture was observed in men over 45 years, but rarely observed in women. Compared to women, men have a higher prevalence of atherosclerosis due to the female sex hormones. Stroke from any cause represents the fifth leading cause of death and the major cause of serious long-term disability in adults. It is reported that nearly $0.25 \%$ of people suffer from stroke every year in the US, resulting in the death of about $18 \%$ of this population [2-4]. In addition, $0.01 \%-0.015 \%$ of acute limb ischemia patients die due to atherosclerosis per year. Therefore, understanding the pathogenesis, mechanism of development, and process of atherosclerosis will lead to therapeutic improvements to reduce its occurrence.

Atherosclerosis is a chronic inflammatory process that leads to the thickening of the intimal layer of large- and medium-sized arteries and results in the formation of plaques. It occurs due to an imbalance between lipid breakdown and the immune response, leading to a failure of inflammatory response resolution [5]. The risk factors of atherosclerosis 
include hypertension, hyperglycemia, obesity, hyperlipidemia, and smoking. An interplay of these risk factors can lead to endothelial activation and dysfunction. Endothelial dysfunction plays an important role in the pathogenesis of atherosclerosis and is a predictor of atherosclerotic risk [6-8]. Endothelial activation leads to oxidative stress, which promotes the generation of reactive oxygen species (ROS) [9]. In addition, endothelial dysfunction promotes the expression of inflammatory cytokines and cell adhesion molecules and increases the permeability of the endothelium, promoting the transmigration of monocytes; this is followed by an accumulation of macrophages and oxidized lipids in the intimal space, which exacerbates the inflammatory process. Monocyte recruitment into the intimal space and their differentiation into macrophages begins early in life and continues into adulthood when there may be a well-defined manifestation of the condition [10-12]. In addition, the inflammatory process is accompanied by vascular smooth muscle migration and inflammation, intimal hyperplasia, fibrosis, and plaque formation [13].

Atherosclerotic plaques narrow the lumen of vessels, obstructing blood flow, making organs susceptible to ischemia; additionally, plaques may rupture, leading to adverse effects such as myocardial ischemia or infarction, renal ischemia, and ischemic stroke due to the activated endothelial and smooth muscle cells, macrophages, lymphocytes, and large amounts of extracellular matrix during the process [14-16]. The characteristics of the cells present in atherosclerotic plaques likely are initiated by the activation of endothelium with the expression of adhesion molecules. These, in turn, enable the adhesion of mononuclear leukocytes, such as monocytes and T-cells, to the endothelium and, also, their transmigration into the intima. The resulting lesions may contain other immune cells, including rare dendritic cells (DCs), neutrophils and B-cells, and smooth muscle cells. These cells transform the original phenotype into synthetic SMC and move into the intima from the media [17]. Indeed, the typical feature of an atherosclerotic vessel is chronic vascular wall inflammation, which can be considered as an unresolved vascular inflammatory response [18].

The endothelial to mesenchymal transition (EndMT) is a process whereby endothelial cells acquire a mesenchymal phenotype; this process plays a key role in vascular inflammation in atherosclerosis $[19,20]$. Recently, the EndMT process has been reported to be associated with additional pathophysiological processes in cardiovascular-related diseases, including atherosclerosis [21,22]. During this process, the endothelial cells lose their apical-to-basal membrane polarity and cell-to-cell adhesion and acquire a migratory, fibroblast-like phenotype. Additionally, there is a suppression of endothelial cell markers including platelet endothelial cell adhesion molecule (PECAM), vascular endothelial cadherin (VE-cadherin), vascular endothelial growth factor 2 receptor (VEGFR-2), and endothelial nitric oxide synthase (eNOS). During EndMT there is also an upregulation of the mesenchymal markers $\alpha$-smooth muscle actin ( $\alpha$-SMA), neural cadherin (N-cadherin), fibroblast-specific protein 1 (FSP1), fibronectin, vimentin, and type I and type III collagen (COL I/III) [23-25] (Figure 1). While EndMT is a normal physiologic process involved in cardiac embryogenesis/septate formation, pathologically its occurrence has been implicated in the initiation, progression, and stabilization of atherosclerotic plaques $[19,20,26]$. Mesenchymal cells play important roles in this disease, including ones in proinflammatory molecule secretion, collagen and metalloproteinase production for plaque calcification and fibrous cap formation. In vivo endothelial cell lineage tracking systems provided evidence that the endothelial cells undergoing EndMT are major contributors to the pool of fibroblast-like cells seen in atherosclerotic plaques as there was co-expression of both endothelial- and mesenchymal-specific markers, and the degree of EndMT correlated with plaque instability $[23,27]$. Although prior studies have typically used constitutively active systems, such as Tie1Cre or Tie2Cre mice, these models have robust Cre recombination in endothelial-derived cells due to the limitation of a majority of circulating leukocytes exhibiting Cre recombination [28]. Later, a tamoxifen-inducible endothelial lineage-tracking system SclCreER ${ }^{\mathrm{T}}$; R26RstopYfp was used; the apolipoprotein E (apoE) homozygous knockout mice $\left(\mathrm{ApoE}^{-/-}\right)$mouse line has been validated and used to study EndMT in vivo [29]. 
In this model, it was confirmed that EndMT-derived fibroblast-like cells are in intimal atherosclerotic plaques and they also found collagen-matrix metalloproteinase (MMP) production. Therefore, collagen-MMP can balance EndMT-derived fibroblast-like cells and destabilize atherosclerotic lesions to enhance clinical disease progression. Furthermore, upon induction of EndMT, there is migration and proliferation of smooth muscle cells through paracrine signaling and this contributes to neointimal hyperplasia, a feature of early atherosclerosis [30]. EndMT is correlated with several risk factors during the atherosclerosis process including hypoxia, TGF- $\beta$ signaling, the inflammatory response, and endothelial dysfunction.

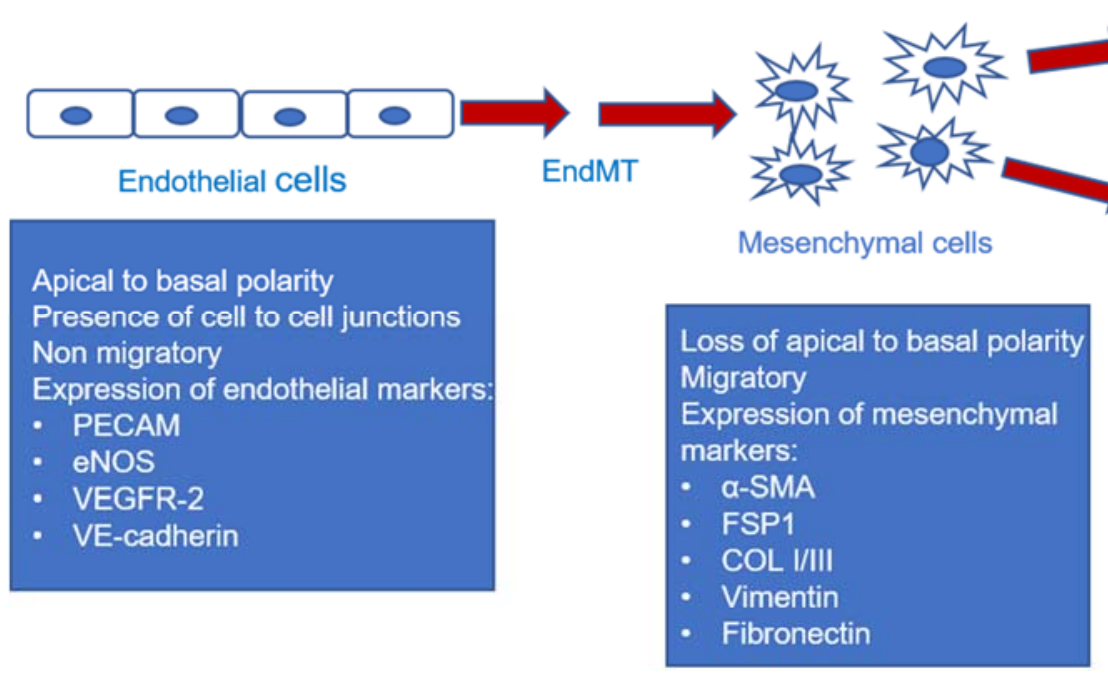

Physiologic process such as cardiac septate formation

Figure 1. Schematic representation of the endothelial to mesenchymal transition during physiological and pathological states. EndMT is accompanied by changes in morphology and cellular markers. There is decreased expression of endothelial markers, PECAM, eNOS, VEGFR-2, VE-cadherin, and an increase in mesenchymal markers, $\alpha$-SMA, N-cadherin, FSP1, COL I/III, vimentin, and fibronectin.

\section{Hypoxia and EndMT in Atherosclerosis}

Atherosclerotic plaques contain a large number of hypoxic cells, and these cells increase as the plaques enlarge. Hypoxia is a well-known promoter of inflammation and EndMT [31-33]. During periods of hypoxia, there is an increase in the expression of hypoxia-inducible factors (HIFs); these are transcription factors that respond to changing levels of oxygen in the cell. Additionally, an impaired proteasomal degradation leads to HIF accumulation in the nucleus [31]. Interestingly, atherosclerotic plaques have been reported to express high levels of HIF mRNA, supporting the presence of a hypoxic microenvironment [34]. Knockdown of HIF in human cardiac microvascular endothelial cells increased their sensitivity to the parasympathetic neurotransmitter acetylcholine (ACh), which significantly repressed hypoxia-induced EndMT [35].

Furthermore, hypoxia increases the level of netrin $1(\mathrm{Ntn} 1)$ in macrophages present in the plaques [36]. Ntn1 protein belongs to the laminin-like family and regulates macrophage trafficking via the Unc-5 netrin receptor B (UNC5B) in human atherosclerotic plaques [37]. Ntn1 serves as a cue in guiding the axons and the neurons to their target during embryogenesis. In atherosclerotic plaques, an increased level of Ntn1 inhibits the emigration of macrophages and promotes macrophage survival in the plaques, thereby exacerbating the inflammatory response and the progression of atherosclerosis. Hypoxia-inducing factor- $1 \alpha$ $(\mathrm{HIF}-1 \alpha)$ is expressed in various cell types within atherosclerotic lesions and is associated with lesional inflammation [36]. In addition, HIF- $1 \alpha$ promotes the polarization of monocytes to the proinflammatory M1 macrophage phenotype and increases their migration into blood vessels, worsening atherosclerosis [38]. Interestingly, Smad2 and the EndMT-induced 
transcription factors, Snail, SLUG, COL1A1, and TWIST, are direct targets of HIF-1 $\alpha$, and their nuclear levels are upregulated during periods of hypoxia. This suggests that hypoxia may play a role in modulating the response of endothelial cells to EndMT-related signaling pathways $[22,39,40]$.

\section{TGF- $\beta$ Signaling and EndMT in Atherosclerosis}

Transforming growth factor receptor $\beta$ (TGF- $\beta$ ) signaling is a known central inducer of EndMT (Figure 2). A common feature of TGF- $\beta$ signaling and EndMT is the increased expression of transcription factors, including Snail, Slug, Twist, LEF-1, ZEB1, and ZEB2, which inhibit the expression of endothelial genes and/or activate expression of mesenchymal genes [41]. Additionally, TGF- $\beta$ is known to control cell proliferation, cell migration, matrix synthesis, wound contraction, calcification, and the immune response, all major components of the atherosclerotic process [42]. There are three isoforms of TGF- $\beta$ (TGF- $\beta 1$, $-\beta 2,-\beta 3)$, and they exert similar functions, albeit there is variability in their expression profiles. Upon binding of TGF- $\beta$ to its ligands, there is recruitment and phosphorylation of several cytoplasmic factors, notably the Smad 2 and Smad 3 proteins, which then bind with Smad4. The resulting transcription factor complex translocates into the nucleus where it interacts with other transcription factors such as Snail, Twist, Snug, and Zeb1 to modulate the expression of genes involved in EndMT. Additionally, the pathway can be inhibited by the activity of the inhibitory Smad proteins Smad 6/Smad 7 [42,43]. Activation of the Snail, Twist, and Zeb proteins decreases the expression of endothelial cell-to-cell adhesion proteins, such as occludin, claudin, and cytokeratin, and upregulates mesenchymal markers [44-46]. Interestingly, small interfering RNA (siRNA) knockdown of Snail prevents TGF- $\beta$-mediated EndMT in human cutaneous microvascular endothelial cells (HCMECs) [47].

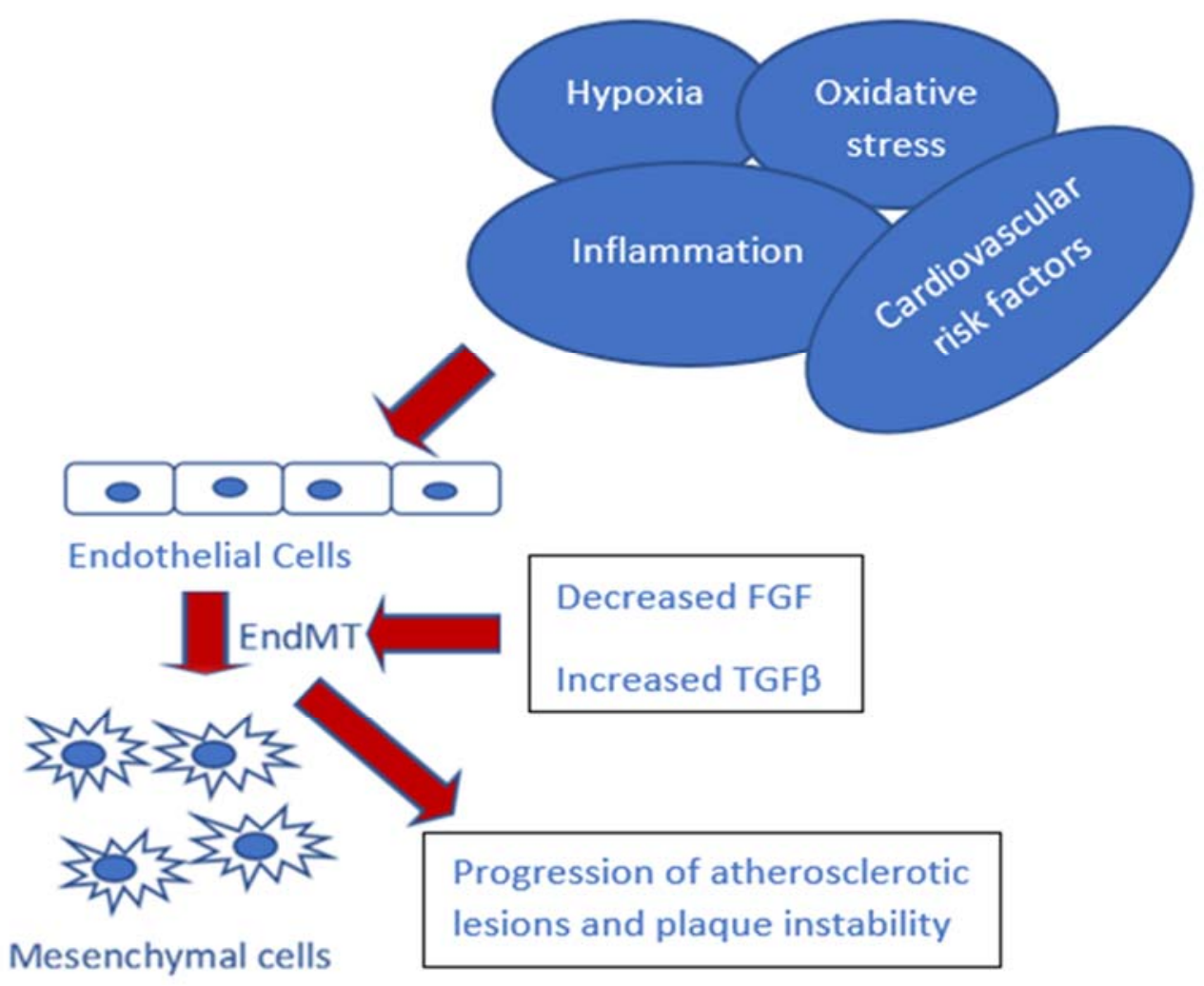

Figure 2. Schematic representation of the mediators of EndMT-induced atherosclerosis. The interplay of hypoxic conditions, oxidative stress, inflammatory injury, and cardiovascular risk factors leads to activation of the EndMT process and dysfunction of the endothelium. Disruption of FGF signaling and upregulation of TGF- $\beta$ signaling promote EndMT. 
TGF- $\beta$ signaling is one of the primary drivers of atherosclerosis-associated vascular inflammation $[19,20,48]$. The activation of TGF- $\beta$, through a Smad2/3-dependent process, promotes inflammation in vitro in cultured human endothelial cells by upregulating the expression of proinflammatory cytokines and chemokines and their receptors, such as CCL2 and CCR2, respectively, as well as adhesion molecules such as ICAM1 and VCAM1. However, TGF- $\beta$ exhibited an anti-inflammatory effect on vascular smooth muscle cells. One can safely say that the response to TGF- $\beta$ is cell type-specific. In vivo knockout of TGF- $\beta$ abrogated inflammation promoted atherosclerotic plaque regression and prevented plaque development [48].

Crosstalk of other signaling pathways (Notch and Wnt) with the TGF- $\beta$ pathway is also involved in the induction of EndMT. Both the Notch and Wnt pathways play crucial roles during cardiac development [49-52]. Microarray studies revealed that the expression of Notch signaling mediators, DLL4, Notch3, and Notch 4, and the Wnt signaling mediators FZD2 and FZD8 were upregulated upon TGF- $\beta$ treatment [53]. Endothelial $\beta$-catenin null mice were also found to have a markedly reduced TGF- $\beta$-induced EndMT [52]. Treatment of human coronary artery endothelial cells (HCAECs) with Notch1 promoted EndMT, as evidenced by the spindle-shaped appearance of the endothelial cells and upregulation of EndMT markers. Furthermore, uniform plaque lesions were noted in in vivo studies [54]. The extent of atherosclerotic lesions is indirectly proportional to the expression of fibroblast growth factors (FGFs) (Figure 2). FGFs are angiogenic factors that help to maintain endothelial function and integrity [55]. They suppress integrin $\beta 1$, a major activator of TGF- $\beta$ /Smad signaling, thereby slowing EndMT and atherosclerotic progression [56,57]. ApoE null mouse models with inducible endothelial-specific deletion of fibroblast growth factor receptor substrate $2 \alpha$ (FRS2 $\alpha$ ), a key signaling mediator, developed early and more extensive atherosclerotic lesions. In addition, there was a marked reduction in expression of fibroblast growth factor receptor 1 (FGFR1) and an upregulation of phosphorylated Smads, a marker of TGF- $\beta$ /Smad pathway activation, in the coronary artery of patients with coronary artery disease compared to patients without coronary artery disease [58]. Although one report found that the absence of endothelial FGFR promoted EndMT-induced atherosclerosis [57], other studies demonstrated that the FGF signaling pathway enhances the progression of atherosclerosis $[59,60]$. Thereby, therapeutic strategies targeting the FGF signaling pathway, such as inhibition of fibroblast growth factor receptor signaling, attenuated atherosclerosis in apolipoprotein E-deficient mice [61]. So far, no synthetic drugs have been found to modulate FGF signaling in EndMT models in vivo. As noted, TGF- $\beta$-driven EndMT is an important contributor to pulmonary fibrosis and pulmonary hypertension. Thus, it might be expected that the local administration of FGF or activation of FGF signaling might have benefits in these conditions [62]. Recent reports indicate that inflammation/EndMT interaction plays a pivotal role in the development of atherosclerosis.

\section{Inflammation and EndMT in Atherosclerosis}

Hypoxia and oxidative stress lead to the induction of inflammation by activating transcription factors. Various in vivo and in vitro studies in humans have shown that the biomarkers of inflammation are associated with cardiovascular events provoked by atherosclerotic plaques [63]. Multifunctional inflammatory cytokines are produced by many inflammatory cells including blood leukocytes, macrophages, smooth muscle cells, and platelets [64]. In vitro studies show that the exposure of primary endothelial cells (ECs) with inflammatory cytokines, including IFN- $\gamma, \mathrm{TNF}-\alpha$, and IL- $1 \beta$, leads to reduced FGFR1 expression. Especially, there is evidence linking the NLRP3 inflammasome and IL-1 cytokines with the pathogenesis of cardiovascular diseases [65]. Additionally, the inflammasome is not only the main pathway for IL- $1 \alpha / \beta$ generation in atherosclerosis but also a target for primary and additional anti-IL-1-directed therapies in high-risk patients [66]. More recently, in vivo studies demonstrated that injection of miR-16 agomiR into $\mathrm{ApoE}^{-/-}$mice reduces the formation of atherosclerotic plaques and inhibits the proinflammatory cytokines, including IL-6, TNF- $\alpha$, MCP-1, and IL- $1 \beta$, in the plasma and tissues, 
but promotes the secretion of anti-inflammatory factors, including IL-10 and TGF- $\beta$. They found that miR-16 might downregulate target program cell death 4 (PDCD4) to activate p38 and ERK1/2 and inactivate the JNK pathway [67]. However, these reports suggest that inhibition of individual inflammatory cytokines is not enough to be effective in treating atherosclerosis. Furthermore, subsequent studies reported that EndMT induction by inflammatory responses leads to pathological states, including tissue fibrosis, pulmonary arterial hypertension, atherosclerosis and dysfunction of the vascular system [68,69]. Ma et al. reported that inflammation reduced CD31 expression and increased $\alpha$-SMA and collagen I expression, which are important markers for cardiac EndMT. They also found that inflammatory stress, including shear stress, oxidative stress and oxidized lipoproteins, exacerbates the progression of cardiac fibrosis in high-fat-fed ApoE KO mice via EndMT, suggesting EndMT and inflammation act synergistically to redistribute plasma lipids to cardiac tissues and accelerate the progression of cardiac fibrosis [70]. EndMT has been found to increase vascular inflammation by TAK 1 and Twist $1 \mathrm{smf}$ promoting the endothelial expression of the inflammatory molecules VCAM-1 and ICAM-1, leading to vascular dysfunction and atherosclerosis [22,71,72]. Sequentially, inflammatory signaling, such as TGF- $\beta 1$ and TGF- $\beta 2$, synergistically promote EndMT in an NFKB-dependent pathway, thus forming a positive regulatory loop for each other [22]. Therefore, these findings suggest EndMT and the inflammation regulatory loop form a common pathological basis for various vascular diseases $[45,73]$.

Furthermore, in vivo studies have implicated numerous inflammatory mediators during the initiation and continued development of atherosclerosis [74]. Initially described during the development of cardiac atrioventricular valves, EndMT has now been identified in different pathologic states characterized by stress conditions, vascular injury, and chronic inflammation [68]. Inflammatory signaling synergizes with the induction of EndMT and inflammatory stress exacerbates cardiac fibrosis progression in high-fat-fed ApoE KO mice [75]. More recently, a study reported that inhibition of miR-122 by regulating NPAS3-mediated EndMT prevents atherosclerotic lesion formation in $\mathrm{ApoE}^{-/-}$mice; this suggests that miR-122 may be a novel target for the treatment of EndMT-associated diseases, including atherosclerosis [76]. Moreover, our collaborators found that C-reactive protein (CRP) is a plasma protein produced by the inflamed liver co-localizes with LDL at atherosclerotic lesions. Administering a mutant CRP to $\mathrm{LDLr}^{-/-}$mice fed a high-fat Western diet (WD) revealed that CRP regulates the development of atherosclerosis. An appropriate inflammatory microenvironment at the site of LDL deposition is critical to prevent atherosclerosis. The function of inflammation could be changed by the modification of proteins' structures, including CRP during the atherosclerotic process [77]. Despite current treatments for atherosclerosis being available, much work still needs to be carried out to reduce the cardiovascular risk that remains. Therefore, inhibiting both inflammation and EndMT may provide a new method for treating atherosclerosis. In addition, chronic inflammation can cause endothelium dysfunction, which is another critical element accounting for atherosclerosis.

\section{Endothelium Dysfunction and EndMT in Atherosclerosis}

Endothelial cells are a monolayer that forms the inner cellular lining of the vascular lumen. In straight sections of a blood vessel, vascular endothelial cells typically align and elongate in the direction of fluid flow. The endothelium forms an interface between circulating blood or lymph in the lumen and the rest of the vessel wall. This forms a barrier between vessels and tissues that controls the flow of substances and fluid into and out of a tissue. This barrier also controls the passage of materials and the transit of white blood cells into and out of the bloodstream. Excessive or prolonged increases in permeability of the endothelium, as in cases of chronic inflammation, may lead to tissue swelling. Therefore, ECs play an important role in maintaining vascular homeostasis and blood fluidity under various physiological processes. These cells can regulate vascular tone, permeability, homeostasis, coagulation, angiogenesis, and inflammatory responses 
via their cell adhesion molecules, cytokines, and chemokines [78-80]. The multiple functions of vascular endothelial cells are illustrated in Figure 3. Endothelium dysfunction is reported to play an important role in atherosclerosis [8,81]. A recent study indicates that the vascular endothelial function contributes to atherosclerosis in patients with nonobstructive coronary artery disease [82]. MMPs are involved in vascular wall remodeling and atherosclerosis development through inflammatory activation and subsequent endothelium dysfunction [83]. Activation of endothelial MMP-2 can induce endothelial loss of integrity and dysfunction [83]. Recruited vascular wall cells can remodel the surrounding extracellular matrix through MMPs that affect migration, proliferation, and apoptosis of endothelial cells and vascular smooth muscle cells (VSMCs) [84].

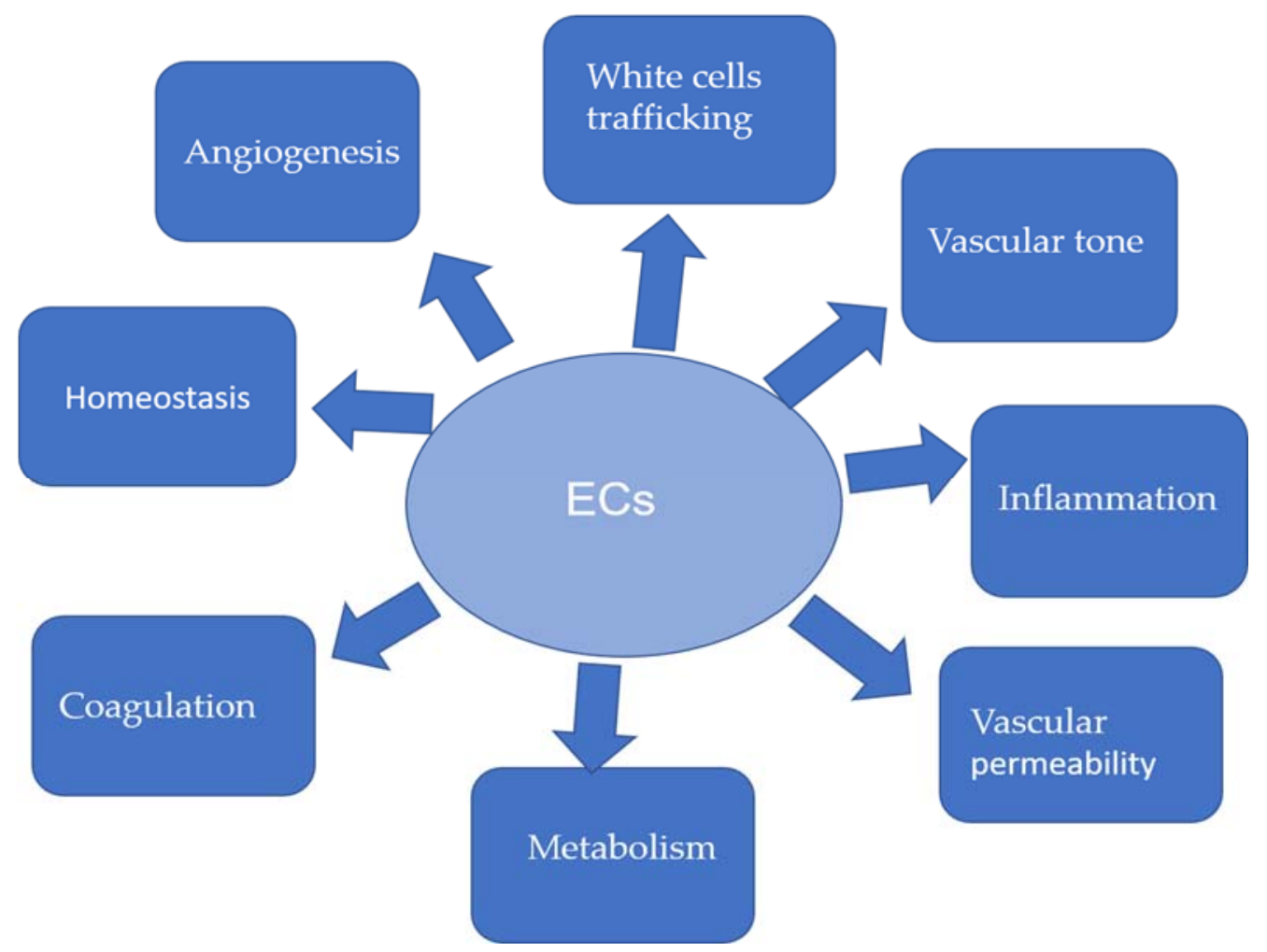

Figure 3. Schematic representation of the multiple functions of vascular endothelial cells.

When the vascular system is injured by abnormal conditions, such as angioplasty, stent, diabetes, hypertension, or immune-mediated damage, the damage will result in endothelial dysfunction $[68,69]$. However, the pathogenesis of atherosclerosis is very complicated and includes endothelial dysfunction, inflammatory response, oxidative stress, smooth muscle cell activation, and thrombosis. However, endothelial dysfunction was considered as the initial factor in inducing atherosclerosis $[85,86]$. Experimental and clinical studies show that ECs can be regenerated by bone marrow-derived circulating endothelial progenitor cells (EPCs), which repair endothelial cell dysfunction and prevent atherosclerosis [82,87]. Moreover, many studies have revealed an association between endothelial dysfunction and inflammatory stress in vascular biology. Under conditions of chronic inflammation, sustained activation of ECs by a dysregulated cytokine release, such as interleukin 6 (IL-6), tumor necrosis factor- $\alpha$ (TNF- $\alpha$ ), IL-1 $\beta$, or an impaired endothelial-dependent immune response can cause endothelial dysfunction [88]. In addition, the NLRP3 inflammasome not only has a role as a critical sensor in the immune response but is also involved in endothelial dysfunction and the pathogenesis of atherosclerosis. NLRP3 inflammasomes regulate caspase- 1 activation and pro-IL- $1 \beta$ processing in macrophages to initiate vascular wall inflammatory responses, which can lead to the progression of atherosclerosis [89]. 
Overexpression of adhesion molecules including ICAM-1 and VCAM-1 has demonstrated that endothelial dysfunction is an early indicator of atherosclerosis [90].

Other mechanisms related to oxidative stress can induce endothelial damage indirectly by reducing PPAR $\gamma$ activity or adiponectin levels. Other studies have shown a protective role by inhibiting endothelial dysfunction via the activation of PPAR $\gamma$ [91,92]. Xu et al. reported that in rat microvascular EC culture, PPAR $\gamma$ agonists reversed oxLDL-induced endothelial dysfunction by stimulating AMP-activated protein kinase (AMPK), which is a serine/threonine-protein kinase that upregulates the Akt/eNOS/NO pathway, enhancing eNOS activity. Consequently, the PPAR $\gamma / \mathrm{AMPK} / \mathrm{eNOS}$ pathway could be a target for the treatment of atherosclerosis. In addition, AMPK has an important role in the prevention of vascular oxidative injury and, hence, endothelial dysfunction since it is a negative regulator of Nox. Some AMPK activators, such as statins, improve endothelial function and have shown antiatherogenic properties. Moreover, the increasing importance of adiponectin is related to the fact that its levels decrease in some cardiovascular diseases such as obesity, type 2 diabetes, metabolic syndrome, or atherosclerosis. In ECs, adiponectin can downregulate the expression of adhesion molecules such as ICAM-1, which promote monocyte adhesion to the vascular endothelium, by inhibiting TNF- $\alpha$-mediated activation of NF-KB. Moreover, high levels of adiponectin could protect against atherosclerosis [93].

Recent evidence suggests that EndMT plays a key role in the complex interactions between inflammatory stress and endothelial dysfunction. Chronic stimulation of ECs by various factors, including pro-inflammatory cytokines and hypoxia, cause ECs to develop an imbalance of endothelial homeostasis, which results in endothelial dysfunction. In vascular diseases, EndMT is a process by which ECs lose their markers and show mesenchymal-like morphological changes and gain mesenchymal cell markers. In cardiovascular disease, EndMT is clearly a pathologic response, probably best viewed as the most extreme phenomenon in the scope of endothelial activation. Therefore, conditions causing endothelial cell activation toward EndMT, including the expression of mesenchymal genes, are detrimental. If this activation happens persistently, over time it may progress to endothelial dysfunction and eventually to a morphological change in cells [94]. EndMTderived cells obtain migratory potential by losing endothelial markers, such as a cluster of differentiation 31 (CD31) and VE-cadherin, which are important to the integrity of the endothelial cobblestone monolayer $[95,96]$. At the same time, the mesenchymal markers, such as fibronectin, $\alpha$-SMA, smooth muscle protein $22 \alpha$, vimentin, and $N$-cadherin, which are involved in an elongated cell phenotype, are upregulated during the EndMT process [96]. The morphology of ECs during EndMT changes from a tight cobblestone monolayer to elongated cells [97]. This phenomenon mainly occurs in various vascular modeling-related diseases, such as pulmonary arterial hypertension (PAH), pulmonary fibrosis, and atherosclerosis. Hence, knowing the pathways implicated in this pathological process of atherosclerosis, including endothelial dysfunction, inflammatory response, and EndMT, helps to develop drugs against incipient atherosclerosis. All of the above are inner factors related to the development of atherosclerosis; however, the environment, as an external factor involved in the formation of atherosclerosis, has been emphasized recently.

\section{Environment Factors in Atherosclerosis}

In addition to the genetic factors, environmental factors are also important in atherosclerosis [98]. Cigarette smoking constitutes a major environmental risk factor for atherosclerosis. Gene-environment interactions have also been demonstrated [99,100]. Indeed, a synergistic effect between cigarette smoking and the carrier state of the ApoE epsilon4 allele increases the risk of atherosclerosis [101]. In addition to these factors, exposure to some chemical substances such as metals, solvents, and persistent organic pollutants, including pesticides, have been reported to be associated with hypertension, atherosclerosis, and cardiovascular diseases [102-105]. Numerous studies have also reported a significant association between imbalances in essential metals and cardiovascular disease risk as metals can induce oxidative stress [106]. Mercury also has been reported to be a risk factor 
in atherosclerosis progression. Most recently, it was reported that mercury can induce atherosclerosis indirectly since it can increase total cholesterol, triglycerides, and LDL levels, and, meanwhile, decrease the HDL level [107]. Therefore, exposure to different chemicals or biological agents may have a direct or inflammatory effect by affecting some molecular mechanism of cardiovascular diseases. So far, we have discussed the aforementioned factors in EndMT and their contributions to atherosclerosis; next, we would like to discuss the newly emerged animal models employed in the study of atherosclerosis.

\section{Mouse Models for Atherosclerosis}

The pathophysiology of human atherosclerosis is a complex process that is impacted by several risk factors, including aging, hyperlipidemia, hypertension, and diabetes. $\mathrm{Al}$ though mouse models are relatively limited to the development of atherosclerosis due to their significantly different lipid profile compared to humans, animal models are still very useful tools to mimic human pathophysiology and study the process of atherosclerosis development and the molecular mechanisms involved. Notably, transgenic and knockout mouse models have proven useful for evaluating atherosclerosis and testing new atherosclerotic drugs during the early stages of atherosclerosis. Several transgenic animal models have been developed for atherosclerosis research over the last several decades. Different animal models can be used depending on the purpose of the research and all of them have advantages and disadvantages, as described in Table 1.

Table 1. The most commonly used mouse models employed in the study of atherosclerosis.

\begin{tabular}{|c|c|c|c|c|}
\hline Model & Characterization & Lipid Change & Plaque Development & $\begin{array}{l}\text { Advantages \& } \\
\text { Disadvantages }\end{array}$ \\
\hline $\mathrm{ApoE}^{-/-}$ & Knockout of ApoE gene & $\mathrm{LDL} \uparrow, \mathrm{HDL} \downarrow$ & Aortic plaques & $\begin{array}{c}\text { Form atherosclerosis } \\
\text { with ND }\end{array}$ \\
\hline $\mathrm{LDLr}^{-/-}$ & Knockout of $L D L r$ gene & $\mathrm{LDL} \uparrow$ & Fibrous plaques & $\begin{array}{c}\text { Close to human lipid } \\
\text { profile; Complex } \\
\text { formation needs WD; } \\
\text { No automatic ruptured } \\
\text { plaques }\end{array}$ \\
\hline $\mathrm{ApoE}^{-/-} \mathrm{LDLr}^{-/-}$ & $\begin{array}{l}\text { Knockout of both } A p o E \\
\text { and } L D L r \text { genes }\end{array}$ & $\mathrm{LDL} \uparrow$ & Fibrosis plaque rupture & $\begin{array}{c}\text { Form atherosclerosis } \\
\text { with ND; plaque } \\
\text { rupture and/or } \\
\text { thrombosis are not } \\
\text { observed }\end{array}$ \\
\hline ApoE*3-Leiden.CETP & $\begin{array}{c}\text { ApoE }^{*} 3 \text {-Leiden } \\
\text { mutation plus the } \\
\text { expression of human } \\
\text { CETP gene }\end{array}$ & $\mathrm{HDL} \uparrow$ & $\begin{array}{l}\text { Extensive } \\
\text { atherosclerosis }\end{array}$ & $\begin{array}{c}\text { A good model for } \\
\text { age-related study; } \\
\text { Lesion formation needs } \\
\text { WD }\end{array}$ \\
\hline PCSK9-AAV & $\begin{array}{c}\text { Adeno-associated virus } \\
\text { injection to control } \\
\text { gain-of-function PCSK9 } \\
\text { mutant }\end{array}$ & $\mathrm{LDL} \uparrow$ & $\begin{array}{l}\text { Quick development of } \\
\text { atherosclerosis plaques }\end{array}$ & $\begin{array}{c}\text { Fast formation of the } \\
\text { atherosclerotic lesion } \\
\text { with WD }\end{array}$ \\
\hline $\begin{array}{l}\text { ApoE }^{-/-} \text {with } \\
\text { angiotensin II infusion }\end{array}$ & $\begin{array}{l}\text { Infusion of angiotensin } \\
\text { II into } \mathrm{ApoE}^{-/-} \text {mice }\end{array}$ & $\mathrm{LDL} \uparrow$ & $\begin{array}{l}\text { Atherosclerosis plaques } \\
\text { rupture }\end{array}$ & $\begin{array}{c}\text { Develops significant } \\
\text { atherosclerotic lesions } \\
\text { with WD }\end{array}$ \\
\hline $\mathrm{ApoE}^{-/-} \mathrm{Fbn1} 1^{\mathrm{C} 1039 \mathrm{G}+/-}$ & $\begin{array}{l}\text { ApoE } E^{-/-} \text {mice with } \\
\text { Fbn1 gene mutation } \\
\text { (C1039G) }\end{array}$ & VLDL个 & $\begin{array}{l}\text { Atherosclerosis plaques } \\
\text { rupture }\end{array}$ & $\begin{array}{c}\text { Fast development of } \\
\text { plaques; Study } \\
\text { advanced } \\
\text { atherosclerosis }\end{array}$ \\
\hline
\end{tabular}


Currently, $\mathrm{ApoE}^{-/-}$mice have been widely used to develop spontaneous hypercholesterolemia and atherosclerosis. However, the LDL receptor knockout ( $\mathrm{LDLr}^{-/-}$) mice respond to high-fat feeding by developing hypercholesterolemia and atherosclerotic lesions $[108,109]$. Using these knockout mice provides important information on the pathogenesis of atherosclerosis. Although both knockout mice models are used to study the mechanisms underlying the initiation and progression of atherosclerosis, their usage is still limited due to the effect on inflammatory processes and lipoprotein metabolism. The $\mathrm{ApoE}^{-/-} / \mathrm{LDLr}^{-/-}$model develops spontaneous atherosclerotic plaques without the complications of plaque rupture and the resulting thrombosis, even on a normal chow $\operatorname{diet}(\mathrm{ND})$ [110]. Recently, it was reported that adeno-associated-virus (AAV)-mediated overexpression of proprotein convertase subtilisin/kexin type 9 (PCSK9) (PCSK9-AAV) rapidly induced hyperlipidemia. There are no genetic modifications in these mice and APOE and LDLR are expressed at normal levels. Additionally, this model requires less time compared to conventional crossbreeding of $\mathrm{ApoE}^{-/-}$and $\mathrm{LDLr}^{-/-}$mice. However, when using this method on C57BL6 wild-type mice, one needs to consider the possible antiviral host immune response of the organism [111].

Although $\mathrm{ApoE}^{-/-} / \mathrm{LDLr}^{-/-}$and PCSK9-AAV mice are valuable tools in atherosclerosis research, many studies utilize ApoE3-Leiden mice. Apolipoprotein (Apo) E3-Leiden is associated with a dominant genetic form of hyperlipidemia occurring in a large Dutch family. ApoE3-Leiden mice were generated using a genomic $27 \mathrm{~kb}$ DNA construct, including the $\mathrm{ApoE}$ gene, $\mathrm{ApoC1}$ gene, and all regulatory elements isolated from the ApoE*3-Leiden proband. These mice develop atherosclerotic lesions in the aorta and large vessels when fed a WD. Remarkably, although these mice are less susceptible to atherosclerosis than the ApoE-deficient mice, they have a human-like lipoprotein profile. Another advantage is that ApoE3-Leiden mice have the ability to synthesize functional ApoE. Compared to the ApoE ${ }^{-/-}$and $\mathrm{LDLr}^{-/-}$mouse models, the ApoE3-Leiden mice allow the study of the effect of elevated plasma lipid levels without disturbing the inflammatory processes, [112]. Another suitable model is the ApoE*3-Leiden.CETP mouse. This model has increased VLDL/LDL cholesterol in the plasma due to the expression of a human cholesteryl ester transfer protein (CETP), a reduced peripheral cholesterol efflux, and advanced atherosclerosis [113]. Recently, a newly developed mouse model is the $\mathrm{ApoE}^{-/-} \mathrm{Fbn} 1^{\mathrm{C} 1039 \mathrm{G}+/-}$ mouse, which is a validated model in pre-clinical studies to evaluate novel plaque-stabilizing drugs [114]. Currently, these mice are considered as the most appropriate model to study advanced atherosclerosis as these mice also form large plaques and are vulnerable to atherosclerotic plaque rupture.

Another use of the $\mathrm{ApoE}^{-/-}$model is to feed the mice with a high-fat diet for 4 weeks with a subsequent infusion of angiotensin II for another 4 weeks. This modified model not only promotes plaque destabilization and stimulates plaque rupture but also has spontaneous atherothrombosis compared to $\mathrm{ApoE}^{-/-}$mice [115]. Therefore, the $\mathrm{ApoE}^{-/-}$plus angiotensin II infusion model is also an alternative model to study advanced atherosclerosis. Taken together, these mouse models continue to be very useful in identifying and describing new triggers and mechanisms regulating the development of atherosclerosis.

\section{Conclusions and Further Direction}

Atherosclerosis is a major cause of mortality and morbidity worldwide with clinical outcomes such as ischemic heart disease, ischemic stroke, renal ischemia, and peripheral vascular disease. The accumulated evidence links EndMT to the initiation and progression of atherosclerosis and plaque instability. Hence, therapies targeting EndMT, including the signaling pathways, could provide an avenue to ameliorate the development of atherosclerosis. For example, the TGF- $\beta$ and FGF signaling pathways can be harnessed as potential targets; however, care should be taken as they are involved in multiple processes in cells that could have unwarranted effects. It will be interesting to find out if inhibiting EndMT would increase the efficacy in the management and treatment of atherosclerosis and the possibility of uncovering new signaling molecules that play a role in EndMT-induced 
atherosclerosis. The new recent findings of EndMT-related signaling pathways in the formation of atherosclerosis have energized efforts to discover therapeutically novel targets other than triglycerides, or perhaps more specifically cholesterol-rich remnant lipoproteins, for atherosclerosis treatment [116]. In addition, accumulating evidence implies that a link between inflammatory pathways and the EndMT signaling pathway is an emerging risk factor to the development of atherosclerosis and its complications. This has led to numerous trials that target these pathways for atherosclerosis therapy. Currently, plenty of clinical studies employ a monoclonal antibody that can neutralize IL-1 $\beta$ or weekly administration of low-dose methotrexate in the treatment of atherosclerosis [117]. It is conceivable that inhibiting EndMT-promoting factors, such as employing antibodies to TGF- $\beta$ ligands and receptors, will significantly improve the efficacy of atherosclerosis treatment. Ultimately, the eventual elimination of atherosclerosis will definitely require multidisciplinary cooperation among public health regulation, applied behavioral psychology, risk factor modulations, improvement of existing therapies, and the development and validation of novel therapeutic approaches.

Author Contributions: J.Z., S.C.O., and Y.J. wrote the manuscript; P.R.M. and Y.J. revised the manuscript according to the comments and suggestions of D.P.T. and Z.Y. All authors have read and agreed to the published version of the manuscript.

Funding: This work was supported by ETSU startup funding E31272.

Institutional Review Board Statement: Not applicable.

Informed Consent Statement: Not applicable.

Data Availability Statement: Not Applicable.

Conflicts of Interest: The authors have no conflict of interest to declare.

\section{Abbreviations}

$\begin{array}{ll}\text { AAV-8 } & \text { adeno-associated-virus-8 } \\ \text { ACh } & \text { acetylcholine } \\ \text { AMPK } & \text { adenosine monophosphate-activated protein kinase } \\ \text { ApoE } & \text { apolipoprotein E } \\ \alpha \text {-SMA } & \text { alpha-smooth muscle actin } \\ \text { ND } & \text { normal diet } \\ \text { COL1A1 } & \text { collagen type I alpha 1 chain } \\ \text { CD31 } & \text { cluster of differentiation 31 } \\ \text { CETP } & \text { cholesteryl ester transfer protein } \\ \text { CRP } & \text { C-reactive protein } \\ \text { DCs } & \text { dendritic cells } \\ \text { EC } & \text { endothelial cell } \\ \text { ECM } & \text { extracellular matrix } \\ \text { EGF } & \text { epidermal growth factor } \\ \text { EndMT } & \text { endothelial to mesenchymal transition } \\ \text { EPC } & \text { endothelial progenitor cell } \\ \text { eNOS } & \text { endothelial nitric oxide synthase } \\ \text { ERK } & \text { extracellular-signal-regulated kinases } \\ \text { FGF } & \text { fibroblast growth factor } \\ \text { FGFR } & \text { fibroblast growth factor receptor } \\ \text { FN } & \text { fibronectin } \\ \text { FSP1 } & \text { fibroblast-specific protein 1 } \\ \text { HCAECs } & \text { human coronary artery endothelial cells } \\ \text { HCMECs } & \text { human cutaneous microvascular endothelial cells } \\ \text { HDL } & \text { high-density lipoprotein } \\ \text { HIFs } & \text { hypoxia-inducible factors } \\ & \end{array}$




$\begin{array}{ll}\text { HUVECs } & \text { human umbilical vein endothelial cells } \\ \text { ICAM } & \text { intercellular adhesion molecule } \\ \text { IGF } & \text { insulin-like growth factor } \\ \text { IL } & \text { interleukin } \\ \text { LDL } & \text { low-density lipoprotein } \\ \text { LDLr } & \text { low-density lipoprotein receptor } \\ \text { MAPK } & \text { mitogen-activated protein kinase } \\ \text { MMP } & \text { matrix metalloproteinase } \\ \text { Ntn1 } & \text { netrin 1 } \\ \text { NLRP3 } & \text { nucleotide-binding domain, leucine-rich-containing family, pyrin } \\ & \text { domain-containing-3 } \\ \text { PAH } & \text { pulmonary arterial hypertension } \\ \text { PCSK9 } & \text { proprotein convertase subtilisin/ kexin type } 9 \\ \text { PDCD4 } & \text { programmed cell death } 4 \\ \text { PECAM } & \text { platelet-endothelial cell adhesion molecule } \\ \text { PDGF } & \text { platelet-derived growth factor } \\ \text { PDR } & \text { proliferative diabetic retinopathy } \\ \text { PGC1 } \alpha & \text { proliferator-activated receptor gamma coactivator 1-alpha TGF- } \beta \\ & \text { transforming growth factor- } \beta \\ \text { PPAR } & \text { peroxisome proliferator-activated receptor } \\ \text { ROS } & \text { reactive oxygen species } \\ \text { siRNA } & \text { small interfering RNA } \\ \text { SLUG } & \text { snail family zinc finger 2 } \\ \text { SMC } & \text { Smooth muscle cell } \\ \text { TGF } \beta \text { R } 1 & \text { transforming growth factor- } \beta \text { receptor 1 } \\ \text { TNF- } \alpha & \text { tumor necrosis factor- } \alpha \\ \text { TWIST } & \text { bHLH transcription factor 1 } \\ \text { UNC5B } & \text { Unc-5 netrin receptor B } \\ \text { VCAM } & \text { vascular cell adhesion molecule } \\ \text { VE-Cadherin } & \text { vascular endothelial-cadherin } \\ \text { VEGF } & \text { vascular endothelial growth factor } \\ \text { VEGFR-2 } & \text { vascular endothelial growth factor 2 receptor } \\ \text { VSMC } & \text { vascular smooth muscle cell } \\ \text { WD } & \text { Western diet } \\ & \end{array}$

\section{References}

1. Agnelli, G.; Belch, J.J.F.; Baumgartner, I.; Giovas, P.; Hoffmann, U. Morbidity and mortality associated with atherosclerotic peripheral artery disease: A systematic review. Atherosclerosis 2020, 293, 94-100. [CrossRef]

2. Obara, H.; Matsubara, K.; Kitagawa, Y. Acute Limb Ischemia. Ann. Vasc. Dis. 2018, 11, 443-448. [CrossRef]

3. Herrington, W.; Lacey, B.; Sherliker, P.; Armitage, J.; Lewington, S. Epidemiology of Atherosclerosis and the Potential to Reduce the Global Burden of Atherothrombotic Disease. Circ. Res. 2016, 118, 535-546. [CrossRef]

4. Whelton, S.P.; Deal, J.A.; Zikusoka, M.; Jacobson, L.P.; Sarkar, S.; Palella, F.J., Jr.; Kingsley, L.; Budoff, M.; Witt, M.D.; Brown, T.T.; et al. Associations between lipids and subclinical coronary atherosclerosis. AIDS 2019, 33, 1053-1061. [CrossRef]

5. Viola, J.; Soehnlein, O. Atherosclerosis-A matter of unresolved inflammation. Semin. Immunol. 2015, 27, 184-193. [CrossRef]

6. Bonetti, P.O.; Lerman, L.O.; Lerman, A. Endothelial dysfunction: A marker of atherosclerotic risk. Arterioscler Thromb. Vasc. Biol. 2003, 23, 168-175. [CrossRef]

7. Verma, I.; Syngle, A.; Krishan, P. Predictors of endothelial dysfunction and atherosclerosis in rheumatoid arthritis in Indian population. Indian Heart J. 2017, 69, 200-206. [CrossRef]

8. Mudau, M.; Genis, A.; Lochner, A.; Strijdom, H. Endothelial dysfunction: The early predictor of atherosclerosis. Cardio Vasc. J. Afr. 2012, 23, 222-231. [CrossRef]

9. Incalza, M.A.; D'Oria, R.; Natalicchio, A.; Perrini, S.; Laviola, L.; Giorgino, F. Oxidative stress and reactive oxygen species in endothelial dysfunction associated with cardiovascular and metabolic diseases. Vascul. Pharmacol. 2018, 100, 1-19. [CrossRef]

10. Martin, L.V.; Jurand, A. The absence of teratogenic effects of some analgesics used in anaesthesia. Additional evidence from a mouse model. Anaesthesia 1992, 47, 473-476. [CrossRef]

11. Stary, H.C. Lipid and macrophage accumulations in arteries of children and the development of atherosclerosis. Am. J. Clin. Nutr. 2000, 72, 1297S-1306S. [CrossRef]

12. Barrett, T.J. Macrophages in Atherosclerosis Regression. Arterioscler Thromb. Vasc. Biol. 2020, 40, 20-33. [CrossRef]

13. Rafieian-Kopaei, M.; Setorki, M.; Doudi, M.; Baradaran, A.; Nasri, H. Atherosclerosis: Process, indicators, risk factors and new hopes. Int. J. Prev. Med. 2014, 5, 927-946. [PubMed] 
14. Lusis, A.J. Atherosclerosis. Nature 2000, 407, 233-241. [CrossRef]

15. Insull, W., Jr. The pathology of atherosclerosis: Plaque development and plaque responses to medical treatment. Am. J. Med. 2009, 122, S3-S14. [CrossRef]

16. Wolf, M.P.; Hunziker, P. Atherosclerosis: Insights into vascular pathobiology and outlook to novel treatments. J. Cardiovasc. Transl. Res. 2020, 13, 744-757. [CrossRef] [PubMed]

17. Ilhan, F.; Kalkanli, S.T. Atherosclerosis and the role of immune cells. World J. Clin. Cases 2015, 3, 345-352. [CrossRef] [PubMed]

18. Hansson, G.K.; Robertson, A.K.; Soderberg-Naucler, C. Inflammation and atherosclerosis. Annu. Rev. Pathol. 2006, 1, 297-329. [CrossRef] [PubMed]

19. Chen, P.Y.; Qin, L.; Baeyens, N.; Li, G.; Afolabi, T.; Budatha, M.; Tellides, G.; Schwartz, M.A.; Simons, M. Endothelial-tomesenchymal transition drives atherosclerosis progression. J. Clin. Investig. 2015, 125, 4514-4528. [CrossRef] [PubMed]

20. Helmke, A.; Casper, J.; Nordlohne, J.; David, S.; Haller, H.; Zeisberg, E.M.; Vietinghoff, S.v. Endothelial-to-mesenchymal transition shapes the atherosclerotic plaque and modulates macrophage function. FASEB J. 2019, 33, 2278-2289. [CrossRef]

21. Ma, X.; Zhao, D.; Yuan, P.; Li, J.; Yun, Y.; Cui, Y.; Zhang, T.; Ma, J.; Sun, L.; Ma, H.; et al. Endothelial-to-Mesenchymal Transition in Calcific Aortic Valve Disease. Acta Cardiol. Sin. 2020, 36, 183-194. [CrossRef]

22. Souilhol, C.; Harmsen, M.C.; Evans, P.C.; Krenning, G. Endothelial-mesenchymal transition in atherosclerosis. Cardio Vasc. Res. 2018, 114, 565-577. [CrossRef]

23. Clere, N.; Renault, S.; Corre, I. Endothelial-to-Mesenchymal Transition in Cancer. Front. Cell Dev. Biol. 2020, 8, 747. [CrossRef] [PubMed]

24. Piera-Velazquez, S.; Jimenez, S.A. Endothelial to Mesenchymal Transition: Role in Physiology and in the Pathogenesis of Human Diseases. Physiol. Rev. 2019, 99, 1281-1324. [CrossRef]

25. Jiang, Y.; Zhou, X.; Hu, R.; Dai, A. TGF-beta1-induced SMAD2/3/4 activation promotes RELM-beta transcription to modulate the endothelium-mesenchymal transition in human endothelial cells. Int. J. Biochem. Cell Biol. 2018, 105, 52-60. [CrossRef]

26. Qin, W.; Zhang, L.; Li, Z.; Xiao, D.; Zhang, Y.; Zhang, H.; Mokembo, J.N.; Monayo, S.M.; Jha, N.K.; Kopylov, P.; et al. Endothelial to mesenchymal transition contributes to nicotine-induced atherosclerosis. Theranostics 2020, 10, 5276-5289. [CrossRef] [PubMed]

27. Evrard, S.M.; Lecce, L.; Michelis, K.C.; Nomura-Kitabayashi, A.; Pandey, G.; Purushothaman, K.R.; d’Escamard, V.; Li, J.R.; Hadri, L.; Fujitani, K.; et al. Corrigendum: Endothelial to mesenchymal transition is common in atherosclerotic lesions and is associated with plaque instability. Nat. Commun. 2017, 8, 14710. [CrossRef] [PubMed]

28. Medici, D.; Shore, E.M.; Lounev, V.Y.; Kaplan, F.S.; Kalluri, R.; Olsen, B.R. Conversion of vascular endothelial cells into multipotent stem-like cells. Nat. Med. 2010, 16, 1400-1406. [CrossRef]

29. Jeong, D.; Lee, M.A.; Li, Y.; Yang, D.K.; Kho, C.; Oh, J.G.; Hong, G.; Lee, A.; Song, M.H.; LaRocca, T.J.; et al. Matricellular Protein CCN5 Reverses Established Cardiac Fibrosis. J. Am. Coll. Cardiol. 2016, 67, 1556-1568. [CrossRef]

30. Moonen, J.R.; Lee, E.S.; Schmidt, M.; Maleszewska, M.; Koerts, J.A.; Brouwer, L.A.; van Kooten, T.G.; van Luyn, M.J.; Zeebregts, C.J.; Krenning, G.; et al. Endothelial-to-mesenchymal transition contributes to fibro-proliferative vascular disease and is modulated by fluid shear stress. Cardio Vasc. Res. 2015, 108, 377-386. [CrossRef]

31. Eltzschig, H.K.; Carmeliet, P. Hypoxia and inflammation. N. Engl. J. Med. 2011, 364, 656-665. [CrossRef] [PubMed]

32. Liu, L.; Chen, J.; Sun, L.; Xu, Y. RhoJ promotes hypoxia induced endothelial-to-mesenchymal transition by activating WDR5 expression. J. Cell Biochem. 2018, 119, 3384-3393. [CrossRef] [PubMed]

33. Xu, X.; Tan, X.; Hulshoff, M.S.; Wilhelmi, T.; Zeisberg, M.; Zeisberg, E.M. Hypoxia-induced endothelial-mesenchymal transition is associated with RASAL1 promoter hypermethylation in human coronary endothelial cells. FEBS Lett. 2016, 590, 1222-1233. [CrossRef] [PubMed]

34. Parathath, S.; Mick, S.L.; Feig, J.E.; Joaquin, V.; Grauer, L.; Habiel, D.M.; Gassmann, M.; Gardner, L.B.; Fisher, E.A. Hypoxia is present in murine atherosclerotic plaques and has multiple adverse effects on macrophage lipid metabolism. Circ. Res. 2011, 109, 1141-1152. [CrossRef]

35. Li, Z.; Li, X.; Zhu, Y.; Chen, Q.; Li, B.; Zhang, F. Protective effects of acetylcholine on hypoxia-induced endothelial-to-mesenchymal transition in human cardiac microvascular endothelial cells. Mol. Cell Biochem. 2020, 473, 101-110. [CrossRef]

36. Ramkhelawon, B.; Yang, Y.; van Gils, J.M.; Hewing, B.; Rayner, K.J.; Parathath, S.; Guo, L.; Oldebeken, S.; Feig, J.L.; Fisher, E.A.; et al. Hypoxia induces netrin-1 and Unc5b in atherosclerotic plaques: Mechanism for macrophage retention and survival. Arterioscler Thromb. Vasc. Biol. 2013, 33, 1180-1188. [CrossRef]

37. van Gils, J.M.; Derby, M.C.; Fernandes, L.R.; Ramkhelawon, B.; Ray, T.D.; Rayner, K.J.; Parathath, S.; Distel, E.; Feig, J.L.; Alvarez-Leite, J.I.; et al. The neuroimmune guidance cue netrin-1 promotes atherosclerosis by inhibiting the emigration of macrophages from plaques. Nat. Immunol. 2012, 13, 136-143. [CrossRef]

38. Aarup, A.; Pedersen, T.X.; Junker, N.; Christoffersen, C.; Bartels, E.D.; Madsen, M.; Nielsen, C.H.; Nielsen, L.B. Hypoxia-Inducible Factor-1alpha Expression in Macrophages Promotes Development of Atherosclerosis. Arterioscler Thromb. Vasc. Biol. 2016, 36, 1782-1790. [CrossRef]

39. Xu, X.; Tan, X.; Tampe, B.; Sanchez, E.; Zeisberg, M.; Zeisberg, E.M. Snail Is a Direct Target of Hypoxia-inducible Factor 1alpha (HIF1alpha) in Hypoxia-induced Endothelial to Mesenchymal Transition of Human Coronary Endothelial Cells. J. Biol. Chem. 2015, 290, 16653-16664. [CrossRef]

40. Zhang, B.; Niu, W.; Dong, H.Y.; Liu, M.L.; Luo, Y.; Li, Z.C. Hypoxia induces endothelialmesenchymal transition in pulmonary vascular remodeling. Int. J. Mol. Med. 2018, 42, 270-278. [CrossRef] 
41. Chen, P.Y.; Simons, M. When endothelial cells go rogue. EMBO Mol. Med. 2016, 8, 1-2. [CrossRef] [PubMed]

42. Toma, I.; McCaffrey, T.A. Transforming growth factor-beta and atherosclerosis: Interwoven atherogenic and atheroprotective aspects. Cell Tissue Res. 2012, 347, 155-175. [CrossRef]

43. Pardali, E.; Ten Dijke, P. TGFbeta signaling and cardiovascular diseases. Int. J. Biol. Sci. 2012, 8, 195-213. [CrossRef]

44. Blobe, G.C.; Schiemann, W.P.; Lodish, H.F. Role of transforming growth factor beta in human disease. N. Engl. J. Med. 2000, 342, 1350-1358. [CrossRef] [PubMed]

45. Kovacic, J.C.; Dimmeler, S.; Harvey, R.P.; Finkel, T.; Aikawa, E.; Krenning, G.; Baker, A.H. Endothelial to Mesenchymal Transition in Cardiovascular Disease: JACC State-of-the-Art Review. J. Am. Coll. Cardiol. 2019, 73, 190-209. [CrossRef] [PubMed]

46. Wesseling, M.; Sakkers, T.R.; de Jager, S.C.A.; Pasterkamp, G.; Goumans, M.J. The morphological and molecular mechanisms of epithelial/endothelial-to-mesenchymal transition and its involvement in atherosclerosis. Vascul. Pharmacol. 2018, 106, 1-8. [CrossRef]

47. Medici, D.; Potenta, S.; Kalluri, R. Transforming growth factor-beta2 promotes Snail-mediated endothelial-mesenchymal transition through convergence of Smad-dependent and Smad-independent signalling. Biochem. J. 2011, 437, 515-520. [CrossRef]

48. Chen, P.Y.; Qin, L.; Li, G.; Wang, Z.; Dahlman, J.E.; Malagon-Lopez, J.; Gujja, S.; Cilfone, N.A.; Kauffman, K.J.; Sun, L.; et al. Endothelial TGF-beta signalling drives vascular inflammation and atherosclerosis. Nat. Metab. 2019, 1, 912-926. [CrossRef]

49. Luxan, G.; D’Amato, G.; MacGrogan, D.; de la Pompa, J.L. Endocardial Notch Signaling in Cardiac Development and Disease. Circ. Res. 2016, 118, e1-e18. [CrossRef]

50. Bosada, F.M.; Devasthali, V.; Jones, K.A.; Stankunas, K. Wnt/beta-catenin signaling enables developmental transitions during valvulogenesis. Development 2016, 143, 1041-1054. [CrossRef]

51. Alfieri, C.M.; Cheek, J.; Chakraborty, S.; Yutzey, K.E. Wnt signaling in heart valve development and osteogenic gene induction. Dev. Biol. 2010, 338, 127-135. [CrossRef] [PubMed]

52. Liebner, S.; Cattelino, A.; Gallini, R.; Rudini, N.; Iurlaro, M.; Piccolo, S.; Dejana, E. Beta-catenin is required for endothelialmesenchymal transformation during heart cushion development in the mouse. J. Cell Biol. 2004, 166, 359-367. [CrossRef] [PubMed]

53. Pinto, M.T.; Ferreira Melo, F.U.; Malta, T.M.; Rodrigues, E.S.; Placa, J.R.; Silva, W.A., Jr.; Panepucci, R.A.; Covas, D.T.; de Oliveira Rodrigues, C.; Kashima, S. Endothelial cells from different anatomical origin have distinct responses during SNAIL/TGF-beta2mediated endothelial-mesenchymal transition. Am. J. Transl. Res. 2018, 10, 4065-4081.

54. Lin, Q.Q.; Zhao, J.; Zheng, C.G.; Chun, J. Roles of notch signaling pathway and endothelial-mesenchymal transition in vascular endothelial dysfunction and atherosclerosis. Eur. Rev. Med. Pharmacol. Sci. 2018, 22, 6485-6491. [CrossRef]

55. Yang, X.; Liaw, L.; Prudovsky, I.; Brooks, P.C.; Vary, C.; Oxburgh, L.; Friesel, R. Fibroblast growth factor signaling in the vasculature. Curr. Atheroscler Rep. 2015, 17, 509. [CrossRef] [PubMed]

56. Li, J.; Shi, S.; Srivastava, S.P.; Kitada, M.; Nagai, T.; Nitta, K.; Kohno, M.; Kanasaki, K.; Koya, D. FGFR1 is critical for the anti-endothelial mesenchymal transition effect of N-acetyl-seryl-aspartyl-lysyl-proline via induction of the MAP4K4 pathway. Cell Death Dis. 2017, 8, e2965. [CrossRef]

57. Chen, P.Y.; Qin, L.; Tellides, G.; Simons, M. Fibroblast growth factor receptor 1 is a key inhibitor of TGFbeta signaling in the endothelium. Sci. Signal. 2014, 7, ra90. [CrossRef]

58. Bolt, H.M.; Filser, J.G.; Stormer, F. Inhalation pharmacokinetics based on gas uptake studies. V. Comparative pharmacokinetics of ethylene and 1,3-butadiene in rats. Arch. Toxicol. 1984, 55, 213-218. [CrossRef]

59. Qi, M.; Xin, S. FGF signaling contributes to atherosclerosis by enhancing the inflammatory response in vascular smooth muscle cells. Mol. Med. Rep. 2019, 20, 162-170. [CrossRef]

60. Chen, P.Y.; Qin, L.; Li, G.; Tellides, G.; Simons, M. Smooth muscle FGF/TGFbeta cross talk regulates atherosclerosis progression. EMBO Mol. Med. 2016, 8, 712-728. [CrossRef] [PubMed]

61. Raj, T.; Kanellakis, P.; Pomilio, G.; Jennings, G.; Bobik, A.; Agrotis, A. Inhibition of fibroblast growth factor receptor signaling attenuates atherosclerosis in apolipoprotein E-deficient mice. Arterioscler Thromb. Vasc. Biol. 2006, 26, 1845-1851. [CrossRef] [PubMed]

62. Xiao, L.; Dudley, A.C. Fine-tuning vascular fate during endothelial-mesenchymal transition. J. Pathol. 2017, 241, 25-35. [CrossRef] [PubMed]

63. Sterpetti, A.V. Inflammatory Cytokines and Atherosclerotic Plaque Progression. Therapeutic Implications. Curr. Atheroscler Rep. 2020, 22, 75. [CrossRef] [PubMed]

64. Branton, M.H.; Kopp, J.B. TGF-beta and fibrosis. Microbes Infect. 1999, 1, 1349-1365. [CrossRef]

65. Abbate, A.; Toldo, S.; Marchetti, C.; Kron, J.; Van Tassell, B.W.; Dinarello, C.A. Interleukin-1 and the Inflammasome as Therapeutic Targets in Cardiovascular Disease. Circ. Res. 2020, 126, 1260-1280. [CrossRef]

66. Jiang, X.; Wang, F.; Wang, Y.; Gistera, A.; Roy, J.; Paulsson-Berne, G.; Hedin, U.; Lerman, A.; Hansson, G.K.; Herrmann, J.; et al. Inflammasome-Driven Interleukin-1alpha and Interleukin-1beta Production in Atherosclerotic Plaques Relates to Hyperlipidemia and Plaque Complexity. JACC Basic Transl. Sci. 2019, 4, 304-317. [CrossRef]

67. Wang, M.; Li, J.; Cai, J.; Cheng, L.; Wang, X.; Xu, P.; Li, G.; Liang, X. Overexpression of MicroRNA-16 Alleviates Atherosclerosis by Inhibition of Inflammatory Pathways. Biomed. Res. Int. 2020, 2020, 8504238. [CrossRef]

68. Chen, P.Y.; Schwartz, M.A.; Simons, M. Endothelial-to-Mesenchymal Transition, Vascular Inflammation, and Atherosclerosis. Front. Cardio Vasc. Med. 2020, 7, 53. [CrossRef] 
69. Cho, J.G.; Lee, A.; Chang, W.; Lee, M.S.; Kim, J. Endothelial to Mesenchymal Transition Represents a Key Link in the Interaction between Inflammation and Endothelial Dysfunction. Front. Immunol. 2018, 9, 294. [CrossRef]

70. Kishimoto, Y.; Kondo, K.; Momiyama, Y. The Protective Role of Sestrin2 in Atherosclerotic and Cardiac Diseases. Int. J. Mol. Sci. 2021, 22, 1200. [CrossRef]

71. Lee, E.S.; Boldo, L.S.; Fernandez, B.O.; Feelisch, M.; Harmsen, M.C. Suppression of TAK1 pathway by shear stress counteracts the inflammatory endothelial cell phenotype induced by oxidative stress and TGF-beta1. Sci. Rep. 2017, 7, 42487. [CrossRef]

72. Mahmoud, M.M.; Kim, H.R.; Xing, R.; Hsiao, S.; Mammoto, A.; Chen, J.; Serbanovic-Canic, J.; Feng, S.; Bowden, N.P.; Maguire, R.; et al. TWIST1 Integrates Endothelial Responses to Flow in Vascular Dysfunction and Atherosclerosis. Circ. Res. 2016, 119, 450-462. [CrossRef]

73. Dejana, E.; Hirschi, K.K.; Simons, M. The molecular basis of endothelial cell plasticity. Nat. Commun. 2017, 8, 14361. [CrossRef]

74. Libby, P. Inflammation in Atherosclerosis-No Longer a Theory. Clin. Chem. 2021, 67, 131-142. [CrossRef]

75. Ma, K.L.; Liu, J.; Ni, J.; Zhang, Y.; Lv, L.L.; Tang, R.N.; Ni, H.F.; Ruan, X.Z.; Liu, B.C. Inflammatory stress exacerbates the progression of cardiac fibrosis in high-fat-fed apolipoprotein E knockout mice via endothelial-mesenchymal transition. Int. J. Med. Sci. 2013, 10, 420-426. [CrossRef]

76. Wu, X.; Du, X.; Yang, Y.; Liu, X.; Liu, X.; Zhang, N.; Li, Y.; Jiang, X.; Jiang, Y.; Yang, Z. Inhibition of miR-122 reduced atherosclerotic lesion formation by regulating NPAS3-mediated endothelial to mesenchymal transition. Life Sci. 2021, 265, 118816. [CrossRef]

77. Pathak, A.; Singh, S.K.; Thewke, D.P.; Agrawal, A. Conformationally Altered C-Reactive Protein Capable of Binding to Atherogenic Lipoproteins Reduces Atherosclerosis. Front. Immunol. 2020, 11, 1780. [CrossRef]

78. Sena, C.M.; Pereira, A.M.; Seica, R. Endothelial dysfunction-A major mediator of diabetic vascular disease. Biochim. Biophys. Acta 2013, 1832, 2216-2231. [CrossRef]

79. Aird, W.C. Endothelial cell heterogeneity. Cold Spring Harb. Perspect Med. 2012, 2, a006429. [CrossRef]

80. Yun, E.; Kook, Y.; Yoo, K.H.; Kim, K.I.; Lee, M.S.; Kim, J.; Lee, A. Endothelial to Mesenchymal Transition in Pulmonary Vascular Diseases. Biomedicines 2020, 8, 639. [CrossRef]

81. Choi, B.J.; Prasad, A.; Gulati, R.; Best, P.J.; Lennon, R.J.; Barsness, G.W.; Lerman, L.O.; Lerman, A. Coronary endothelial dysfunction in patients with early coronary artery disease is associated with the increase in intravascular lipid core plaque. Eur. Heart J. 2013, 34, 2047-2054. [CrossRef] [PubMed]

82. Li, Y.P.; Fan, Z.X.; Gao, J.; Sun, X.P.; Zhu, G.H.; Zhang, Y.H.; Si, J.; Zuo, X.B.; Liu, Z.; Hua, Q.; et al. Influencing factors of vascular endothelial function in patients with non-obstructive coronary atherosclerosis: A 1-year observational study. BMC Cardio Vasc. Disord. 2020, 20, 40. [CrossRef] [PubMed]

83. Carmona-Rivera, C.; Zhao, W.; Yalavarthi, S.; Kaplan, M.J. Neutrophil extracellular traps induce endothelial dysfunction in systemic lupus erythematosus through the activation of matrix metalloproteinase-2. Ann. Rheum. Dis. 2015, 74, 1417-1424. [CrossRef] [PubMed]

84. Amato, B.; Compagna, R.; Amato, M.; Grande, R.; Butrico, L.; Rossi, A.; Naso, A.; Ruggiero, M.; de Franciscis, S.; Serra, R. Adult vascular wall resident multipotent vascular stem cells, matrix metalloproteinases, and arterial aneurysms. Stem Cells Int. 2015, 2015, 434962. [CrossRef] [PubMed]

85. Wu, M.Y.; Li, C.J.; Hou, M.F.; Chu, P.Y. New Insights into the Role of Inflammation in the Pathogenesis of Atherosclerosis. Int. J. Mol. Sci. 2017, 18, 2034. [CrossRef]

86. Varghese, J.F.; Patel, R.; Yadav, U.C.S. Novel Insights in the Metabolic Syndrome-induced Oxidative Stress and Inflammationmediated Atherosclerosis. Curr. Cardiol. Rev. 2018, 14, 4-14. [CrossRef] [PubMed]

87. Suzuki, R.; Fukuda, N.; Katakawa, M.; Tsunemi, A.; Tahira, Y.; Matsumoto, T.; Ueno, T.; Soma, M. Effects of an angiotensin II receptor blocker on the impaired function of endothelial progenitor cells in patients with essential hypertension. Am. J. Hypertens 2014, 27, 695-701. [CrossRef]

88. Perez, L.; Munoz-Durango, N.; Riedel, C.A.; Echeverria, C.; Kalergis, A.M.; Cabello-Verrugio, C.; Simon, F. Endothelial-tomesenchymal transition: Cytokine-mediated pathways that determine endothelial fibrosis under inflammatory conditions. Cytokine Growth Factor Rev. 2017, 33, 41-54. [CrossRef]

89. Karasawa, T.; Takahashi, M. Role of NLRP3 Inflammasomes in Atherosclerosis. J. Atheroscler Thromb. 2017, 24, 443-451. [CrossRef] [PubMed]

90. Habas, K.; Shang, L. Alterations in intercellular adhesion molecule 1 (ICAM-1) and vascular cell adhesion molecule 1 (VCAM-1) in human endothelial cells. Tissue Cell 2018, 54, 139-143. [CrossRef]

91. Locatelli, L.; Fedele, G.; Castiglioni, S.; Maier, J.A. Magnesium Deficiency Induces Lipid Accumulation in Vascular Endothelial Cells via Oxidative Stress-The Potential Contribution of EDF-1 and PPARgamma. Int. J. Mol. Sci. 2021, 22, 1050. [CrossRef]

92. Xu, L.; Wang, S.; Li, B.; Sun, A.; Zou, Y.; Ge, J. A protective role of ciglitazone in ox-LDL-induced rat microvascular endothelial cells via modulating PPARgamma-dependent AMPK/eNOS pathway. J. Cell Mol. Med. 2015, 19, 92-102. [CrossRef]

93. Yanai, H.; Yoshida, H. Beneficial Effects of Adiponectin on Glucose and Lipid Metabolism and Atherosclerotic Progression: Mechanisms and Perspectives. Int. J. Mol. Sci. 2019, 20, 1190. [CrossRef]

94. Schwartz, M.A.; Vestweber, D.; Simons, M. A unifying concept in vascular health and disease. Science 2018, 360, $270-271$. [CrossRef] [PubMed]

95. Ranchoux, B.; Antigny, F.; Rucker-Martin, C.; Hautefort, A.; Pechoux, C.; Bogaard, H.J.; Dorfmuller, P.; Remy, S.; Lecerf, F.; Plante, S.; et al. Endothelial-to-mesenchymal transition in pulmonary hypertension. Circulation 2015, 131, 1006-1018. [CrossRef] 
96. Ursoli Ferreira, F.; Eduardo Botelho Souza, L.; Hassibe Thome, C.; Tomazini Pinto, M.; Origassa, C.; Salustiano, S.; Marcel Faca, V.; Olsen Camara, N.; Kashima, S.; Tadeu Covas, D. Endothelial Cells Tissue-Specific Origins Affects Their Responsiveness to TGF-beta2 during Endothelial-to-Mesenchymal Transition. Int. J. Mol. Sci. 2019, 20, 458. [CrossRef]

97. Sanchez-Duffhues, G.; Garcia de Vinuesa, A.; Ten Dijke, P. Endothelial-to-mesenchymal transition in cardiovascular diseases: Developmental signaling pathways gone awry. Dev. Dyn. 2018, 247, 492-508. [CrossRef] [PubMed]

98. Mertens, G. Gene/Environment interaction in atherosclerosis: An example of clinical medicine as seen from the evolutionary perspective. Int. J. Hypertens 2010, 2010, 654078. [CrossRef] [PubMed]

99. Aherrahrou, R.; Guo, L.; Nagraj, V.P.; Aguhob, A.; Hinkle, J.; Chen, L.; Yuhl Soh, J.; Lue, D.; Alencar, G.F.; Boltjes, A.; et al. Genetic Regulation of Atherosclerosis-Relevant Phenotypes in Human Vascular Smooth Muscle Cells. Circ. Res. 2020, 127, $1552-1565$. [CrossRef] [PubMed]

100. Boua, P.R.; Brandenburg, J.T.; Choudhury, A.; Hazelhurst, S.; Sengupta, D.; Agongo, G.; Nonterah, E.A.; Oduro, A.R.; Tinto, H.; Mathew, C.G.; et al. Novel and Known Gene-Smoking Interactions With cIMT Identified as Potential Drivers for Atherosclerosis Risk in West-African Populations of the AWI-Gen Study. Front. Genet. 2019, 10, 1354. [CrossRef]

101. Zak, I.; Niemiec, P.; Balcerzyk, A.; Krauze, J. Combined "pro-atherosclerotic" variants of the ACE and APOE genes increase the risk of the coronary artery disease associated with the presence of cigarette smoking. Acta Cardiol. 2008, 63, 741-747. [CrossRef] [PubMed]

102. Lind, P.M.; Lind, L. Are Persistent Organic Pollutants Linked to Lipid Abnormalities, Atherosclerosis and Cardiovascular Disease? A Review. J. Lipid Atheroscler 2020, 9, 334-348. [CrossRef] [PubMed]

103. Solenkova, N.V.; Newman, J.D.; Berger, J.S.; Thurston, G.; Hochman, J.S.; Lamas, G.A. Metal pollutants and cardiovascular disease: Mechanisms and consequences of exposure. Am. Heart J. 2014, 168, 812-822. [CrossRef]

104. Paul, M.; O’Hara, L.; Tah, P.; Street, C.; Maras, A.; Ouakil, D.P.; Santosh, P.; Signorini, G.; Singh, S.P.; Tuomainen, H.; et al. A systematic review of the literature on ethical aspects of transitional care between child- and adult-orientated health services. BMC Med. Ethics 2018, 19, 73. [CrossRef]

105. Carvalho, T.G.S.; Tavares, N.H.; Bastos, M.L.A.; Oliveira, B.B.R.; Araujo, L.F.; Ferreira, M.J.M. Exposure to Chemical and Biological Agents at Work and Cardiovascular Disease in Brazil: A Population-Based Study. J. Occup. Environ. Med. 2021. [CrossRef]

106. Chowdhury, R.; Ramond, A.; O’Keeffe, L.M.; Shahzad, S.; Kunutsor, S.K.; Muka, T.; Gregson, J.; Willeit, P.; Warnakula, S.; Khan, H.; et al. Environmental toxic metal contaminants and risk of cardiovascular disease: Systematic review and meta-analysis. BMJ 2018, 362, k3310. [CrossRef] [PubMed]

107. Farkhondeh, T.; Afshari, R.; Mehrpour, O.; Samarghandian, S. Mercury and Atherosclerosis: Cell Biology, Pathophysiology, and Epidemiological Studies. Biol. Trace Elem. Res. 2020, 196, 27-36. [CrossRef]

108. Oppi, S.; Luscher, T.F.; Stein, S. Mouse Models for Atherosclerosis Research-Which Is My Line? Front. Cardio Vasc. Med. 2019, 6, 46. [CrossRef] [PubMed]

109. Golforoush, P.; Yellon, D.M.; Davidson, S.M. Mouse models of atherosclerosis and their suitability for the study of myocardial infarction. Basic Res. Cardiol. 2020, 115, 73. [CrossRef]

110. Jawien, J.; Nastalek, P.; Korbut, R. Mouse models of experimental atherosclerosis. J. Physiol. Pharmacol. $2004,55,503-517$.

111. Kumar, S.; Kang, D.W.; Rezvan, A.; Jo, H. Accelerated atherosclerosis development in C57Bl6 mice by overexpressing AAVmediated PCSK9 and partial carotid ligation. Lab. Investig. 2017, 97, 935-945. [CrossRef] [PubMed]

112. Parma, L.; Peters, H.A.B.; Sluiter, T.J.; Simons, K.H.; Lazzari, P.; de Vries, M.R.; Quax, P.H.A. bFGF blockade reduces intraplaque angiogenesis and macrophage infiltration in atherosclerotic vein graft lesions in ApoE3*Leiden mice. Sci. Rep. 2020, 10, 15968. [CrossRef] [PubMed]

113. In Het Panhuis, W.; Kooijman, S.; Brouwers, B.; Verhoeven, A.; Pronk, A.C.M.; Streefland, T.C.M.; Giera, M.; Schrauwen, P.; Rensen, P.C.N.; Schonke, M. Mild Exercise Does Not Prevent Atherosclerosis in APOE*3-Leiden.CETP Mice or Improve Lipoprotein Profile of Men with Obesity. Obesity 2020, 28 (Suppl. 1), S93-S103. [CrossRef]

114. Perrotta, P.; Van der Veken, B.; Van Der Veken, P.; Pintelon, I.; Roosens, L.; Adriaenssens, E.; Timmerman, V.; Guns, P.J.; De Meyer, G.R.Y.; Martinet, W. Partial Inhibition of Glycolysis Reduces Atherogenesis Independent of Intraplaque Neovascularization in Mice. Arterioscler Thromb. Vasc. Biol. 2020, 40, 1168-1181. [CrossRef] [PubMed]

115. Xue, F.; Yang, J.; Cheng, J.; Sui, W.; Cheng, C.; Li, H.; Zhang, M.; Zhang, J.; Xu, X.; Ma, J.; et al. Angiotensin-(1-7) mitigated angiotensin II-induced abdominal aortic aneurysms in apolipoprotein E-knockout mice. Br. J. Pharmacol. 2020, 177, 1719-1734. [CrossRef]

116. Libby, P.; Bornfeldt, K.E.; Tall, A.R. Atherosclerosis: Successes, Surprises, and Future Challenges. Circ. Res. 2016, 118, 531-534. [CrossRef]

117. McPherson, R.; Tybjaerg-Hansen, A. Genetics of Coronary Artery Disease. Circ. Res. 2016, 118, 564-578. [CrossRef] 